\title{
CORRELATION BETWEEN DOMESTIC VIOLENCE AGAINST WOMEN AND NEUROTICISM
}

\author{
Numanovic S. Almedina, ${ }^{1}$ Jovicic M. Milena ${ }^{2}$ \\ ${ }^{1}$ International University of Novi Pazar, Novi Pazar, Serbia \\ ${ }^{2}$ Clinical Center Kragujevac, Psychiatric Clinic, Kragujevac, Serbia
}

Primljen/Received 01. 12. 2014. god.

Abstract: Objective: The aim of the study was to determine the degree of correlation between domestic violince against women and neuroticism. Socio-demographics characzeristics were also compared.

Method: This research included 120 women from Novi Pazar and Sjenica, 60 women who were victims of domestic violence and 60 women who were not violence victims. The degree of neuroticism has been tested with general neuroticism test.

Results: There is significant difference between women who were violnce victims and those who were not, on 0.05 level (with $5 \%$ risk), $\mathrm{t}=2.112, \mathrm{p}=0.039$. Arithmetic mean of the degree of neuroticism of women who were violence victims is 78,89 , for those who were not is 38,69 . The difference is important (about 40). There is statistically significant difference between married and single women who were violence victims. Married examinees have higher degree of neuroticism than single ones. Examinees with higher degree of neuroticism have been suffering from domestic violence longer than those with less degree of neuroticism. There is no statistically significant difference in the the degree of neuroticism between different categories of examinees, according to the degree of profesional qualifications.

Conclusion: It remains an open question, and it is necessary to longitudinally examine what is the role of violence against women in the emergence neurotic and other disorders.

Key words: violence against women, neuroticism, neurosis.

\section{INTRODUCTION}

Violence is the use of an absolute or psychological force to another person. The violence is a pervasive phenomenon that manifests itself in a number of forms:
Prihvaćen/Accepted 20. 12. 2014. god.

physical violence, verbal abuse, domestic violence, violence against children, violence in the workplace, instrumental violence, actual violence, potential violence, motivated violence, etc. (1).

Domestic violence always represents an abuse of power and the exercise of control over family members who have less power and have less resources (2).

Domestic violence is the behaviour of a family memeber endangering the physical integrity, mental health or tranquility of another family member according to Legislation on Domestic Violence in Serbia (article 197, pg 3) (3). Domestic violence is a term that usually refers to violence between spouses or spousal abuse, but it can also applies to unmarried intimate partners or just people who live together. Domestic violence is a phenomenon that is present in all countries and in all cultures; people of all races, ethnicities, religious, and political and sexual orientation, social and cultural levels and genders can be perpetrators of domestic violence.

The awareness of domestic violence as well as understanding and documentations of this offense vary from country to country. It is estimated that in the United States and Great Britain only a third of cases of domestic violence reported to the police (4).

The most common victims of domestic violence are women and that is the reason we call it even gender based violence. The family is a social institution with most violence cases, except for the army during the war. According to the UN, the leading cause of death and disability for women between 15-45 years are not an illness or a car accident, but the violence, and the most dangerous place for a woman is her own home (5).

Women are often victims of their loved ones. Domestic violence is the most common form of the more general problem of violence against women, which speak in favor of the statistics: between $40 \%$ and $70 \%$ 
of murders where the the victims were women, the perpetrators were their husbands or fiancés. It was also reported that it is not always about physical violence, but also mental or verbal. Violence against women exercising their sentimental partners most often unreported to the police, so that experts believe that the number of women victims of domestic violence is much higher than when the statistics show that it is difficult to assess.

Although this problem is presented as a problem within heterosexual relationships, it still exists among lesbians, or between mother and daughter, between two women who share a flat or in any other relationship between the two women living under the same roof. Violence against women in lesbian relationships are almost equally represented as in heterosexual relationships.

The most common perpetrators of violence against women by their intimate male partners, whether that violence occurs in the context of living together in a household, or during occasional sightings. In $96 \%$ of cases in heterosexual intimate relationships, the perpetrator is a man and the victim's wife, and therefore it is not clear why the priority given to the measures and activities aimed at combating violence against women and their consequences (6).

The definition of violence against women by the United Nations documents:

Violence against women is a manifestation of historically unequal relations of social power between men and women which have led to domination over and discrimination against women by men up to prevent the full advancement of women. Violence against women is one of the crucial social mechanisms by which women are forced into a subordinate position compared with men. Violence against women is an obstacle to the achievement of equality, development and the peace (7).

Violence against women in intimate relationships is the result of an imbalance of power between women and men (8).

Neurosis is a psychomatic phenomena occurred because of vegetative nervous system disorder caused by mental stimuli (9). Some authors consider psychoneuroses identical neuroses, while other believe there is a difference because neurosis have somatic origin, while psychoneurosis does not, also neurosis is disorder of somatic functions, that does not have mental content, while psychoneuroses do have, and also a shorter duration, on the other side, psychoneuroses last longer. The name neurosis was introduced by Cullen who wanted to indicate that it is general disorder of the nervous. The term included all disorders of nervous system that do not have migraine or physical lesions, an illness considered to be neurosis (10). Many experts consider to be more appropriate to say about different types of neuroses. The cause of neuroses generally lies in failure of an individual to satisfy certain motives, for him, very strong motives or to get rid of some conflict situation (10).

The clinical indicators of neuroticism (clinical assessment): badly or poorly organized personality, dependance, narrow interests, the lack of energy, abnormality before an illness, weak muscle tone, an isolation and the feeling of not belonging.

Self-assessment: the feeling of inferiority, anxiety or nervousness, tendency for an accident, avoidance and failure to report efforts, dissatisfaction, sensitivity, irritability and easy offensiveness. Constitutional characteristics: poor physical stamina and physical activity, inadequate body composition, poor vision in the dark or in twilight (10).

\section{OBJECTIVE}

The aim of the study was to determine the degree of correlation between domestic violince against women and neuroticism. Socio-demographics characzeristics were also compared.

\section{METHODS}

This research included 120 women from Novi Pazar and Sjenica, 60 women who were victims of domestic violence and 60 women who were not violence victims, age 18-65, average age was 39.12 ( $\mathrm{SD}=9.56$ ). Respondents were of diffferent educational level, most of them had Associate Degree (61.67\%). Criteria for testing were a) the respondent is not under $18, \mathrm{~b}$ ) the respondent can write and read in serbian, c)the respondent experienced some form of abuse in the past year. Criteria for taking out of testing were a)the respondent has experienced at least one of the following events over the past year : traffic accidents, earthquake, flood, fire; b) The respondent has actual diagnosis of a psychotic disorder, c) the respondents has abused some of psychoactive substances.

Respondents were given the general neuroticism test, Cornell index (CI-N4). Cornell index is assigned to preliminary neoroticism diagnosis. It includes three scales: HY scale- elevated value on this scale indicates neorotic disorders ,such as psychosomatic, hysterical or conversion disorder; ALPHA scale- elevated value on this scale indicates anxiety, phobia, obsession, compulsion and depression; SIGMA scale- elevated value on this scale indicates aggressiveness of neurotic character. The test consist of 110 questions in which the respondent should respond with true $(\mathrm{T})$ if she agree with the statement or false (N), if she disagrees. Cornell index can be applied individually and in groups, but you 
can explain aforementioned scales only for individual testing, because the results are assessed on the basis of the total score, which is the sum of correct answers.

Retrospective study has been used. For statistical analysis we used the methods of descriptive statistics, $t$ test and Spearman's correlation coefficient. Data processing was performed using SPSS 18.

\section{RESULTS}

Arithmetic mean of the degree of neuroticism of women who were violence victims is 78.89 , for those who were not is 38.69 . The difference is important (about 40).

In order to establish wheather there is a difference in neuroticism between the control and experimental groups, we used the t-test for independent samples, and the following results were obtained (Table 2):

Based on results (Table 2) we see that t-test is important $(t=2.12, p=0.039)$. That there is a statistically significant difference depends on neurotiscm between patients who have suffered violence and those who are not at the level of 0.05 (with a risk of 5\%). The results of the correlation between neuroticism and age of respondents victims of violence are shown in Table 3.

Based on the obtained results (Table 3) we may notice that between variables neuroticism and age there is a very low correlation (0.005), which was not statistically significant $(\mathrm{p}>0.05)$.

By comparing the data on marital status and level of neuroticism, we came up with the following results shown in Table 4 and Table 5.

Table 1. The significance of differences in neuroticism among respondents who were suffering violence and control group

\begin{tabular}{|c|c|c|c|c|c|}
\hline & respondents & $\mathrm{N}$ & $\begin{array}{c}\text { Arithmetic } \\
\text { mean }\end{array}$ & $\begin{array}{c}\text { Standard } \\
\text { deviation }\end{array}$ & $\begin{array}{c}\text { Standard error } \\
\text { of the arithmetic } \\
\text { mean }\end{array}$ \\
\hline Neuroticsm & $\begin{array}{c}\text { women who have suffered } \\
\text { violence }\end{array}$ & 60 & 78.89 & 11.55 & 1.24 \\
\cline { 2 - 6 } & $\begin{array}{c}\text { women who have not } \\
\text { suffered violence }\end{array}$ & 60 & 38.69 & 5.36 & 0.93 \\
\hline
\end{tabular}

Table 2. The significance of differences in neuroticism among respondents who were suffering violence and control groups

\begin{tabular}{|c|c|c|c|c|c|}
\hline neuroticsm & $\begin{array}{c}\mathrm{F} \\
\text { Levene's test }\end{array}$ & Significance & $\mathrm{T}$ & $\mathrm{df}$ & Significance \\
\hline Equal variances assumed & 2.474 & 0.121 & 2.112 & 62 & 0.039 \\
\hline $\begin{array}{c}\text { The result of variances that } \\
\text { are not expected }\end{array}$ & & & 2.069 & 52.973 & 0.043 \\
\hline
\end{tabular}

Table 3. The significance of the correlation between the degree of neuroticism and age of the respondents the victims of violence

\begin{tabular}{|l|c|c|c|}
\hline \multirow{4}{*}{ neuroticsm } & & neuroticsm & age \\
\hline \multirow{3}{*}{ age } & Pearson's correlation coefficient & 1.000 & 0.005 \\
\cline { 2 - 4 } & Significance & & 0.692 \\
\cline { 2 - 4 } & $\mathrm{N}$ & & 60 \\
\hline \multirow{3}{*}{} & Pearson's correlation coefficient & & 1.000 \\
\cline { 2 - 4 } & Significance & 0.692 & \\
\cline { 2 - 4 } & $\mathrm{N}$ & 60 & \\
\hline
\end{tabular}

Table 4. The significance of differences in neuroticism among respondents with different marital status (married-divorced)

\begin{tabular}{|c|c|c|c|c|c|}
\hline & Marital status & $\mathrm{N}$ & Arithmetic mean & $\begin{array}{c}\text { Standard } \\
\text { deviation }\end{array}$ & $\begin{array}{c}\text { Standard error of } \\
\text { arithmetic mean }\end{array}$ \\
\hline \multirow{2}{*}{$\begin{array}{c}\text { The degree of } \\
\text { neuroticism }\end{array}$} & married & 35 & 79.16 & 7.59 & 1.00 \\
\cline { 2 - 6 } & unmarried & 25 & 65.70 & 7.90 & 1.15 \\
\hline
\end{tabular}


From the obtained data (Table 4, Table 5) we see that between married an unmarried respondents, the victims of domestic violence, there is a statistically significant difference(at the level of 0.05 i.e. the risk is $5 \%$ ) in the level of neuroticism. Married respondents have higher levels of neuroticism than the unmarried. Arithmetic mean neuroticism for married respondents is 79.16 , while unmarried 65.70 .

Married respondents have higher levels of neuroticism than the unmarried. Arithmetic mean neuroticism for married respondents is 79.16 , while unmarried 65.70 .

We also evaluated the degree of neuroticism in relation to the timeframe (expressed in years) during which the respondents suffered violence. Pearson coefficient results are shown in Table 6 )
Pearson's correlation coefficient (Table 6) is 0.871 , which means that the correlation is very high, and on the basis of significance, we conclude that the relationship between the degree of neuroticism and timeframe (expressed in years) during which the respondents suffered violence, it is also statistically significant, $\mathrm{p}<0.05(\mathrm{p}=0.000)$.

Namely, respondents with higher levels of neuroticism, who suffered the violence for much longer period of time than women with lower levels of neuroticism.

In assessing whether there is statistically significant difference in the degree neuroticism of patients, victims of violence, in relation to the level of qualifications, we obtained the results shown in Table 7 and Table 8.

The results (Table 7) shows that there are no large discrepancies in arithmetic mean of the degree of neu-

Table 5. The significance of differences in neuroticism among respondents with different marital status (married-divorced)

\begin{tabular}{|c|c|c|c|c|c|c|c|}
\hline & $\begin{array}{c}\mathrm{F} \\
\text { Levene's } \\
\text { test }\end{array}$ & $\begin{array}{c}\text { Signifi- } \\
\text { cance }\end{array}$ & $\mathrm{T}$ & Df & $\begin{array}{c}\text { Signifi- } \\
\text { cance }\end{array}$ & $\begin{array}{c}\text { The } \\
\text { difference } \\
\text { between } \\
\text { the } \\
\text { arithmetic } \\
\text { mean }\end{array}$ & $\begin{array}{c}\text { Standrad } \\
\text { error of } \\
\text { the } \\
\text { arithmetic } \\
\text { mean }\end{array}$ \\
\hline The expected variances & 0.427 & 0.515 & 2.277 & 103 & 0.025 & 3.45 & 1.52 \\
\hline The unexpected variances & & & 2.267 & 96.795 & 0.026 & 3.45 & 1.52 \\
\hline
\end{tabular}

Table 6. The significance of the correlation between the degree of neuroticism and the timeframe in which the respondent suffered violence

\begin{tabular}{|c|c|c|c|}
\hline & & $\begin{array}{l}\text { The digree } \\
\text { of neuroticism }\end{array}$ & $\begin{array}{l}\text { Timeframe (expressed } \\
\text { in years) during which the } \\
\text { respondents suffered violence }\end{array}$ \\
\hline \multirow{3}{*}{$\begin{array}{l}\text { The digree } \\
\text { of neuroticism }\end{array}$} & $\begin{array}{c}\text { Pearson's correlation } \\
\text { coefficient }\end{array}$ & 1.000 & 0.873 \\
\hline & Significance & & 0.000 \\
\hline & $\mathrm{N}$ & & 60 \\
\hline \multirow{3}{*}{$\begin{array}{l}\text { Timeframe (expressed in } \\
\text { years) during which the } \\
\text { respondents suffered violence }\end{array}$} & $\begin{array}{c}\text { Pearson's correlation } \\
\text { coefficient }\end{array}$ & & 1.000 \\
\hline & Significance & 0.000 & \\
\hline & $\mathrm{N}$ & 60 & \\
\hline
\end{tabular}

Table 7. Arithmetic means, standard deviations and standard errors (ar. Mid), of the degree of neuroticism of respondents with different levels of educational attainment

\begin{tabular}{|c|c|c|c|c|}
\hline & $\mathrm{N}$ & $\begin{array}{c}\text { Arithmetic } \\
\text { mean }\end{array}$ & $\begin{array}{c}\text { Standard } \\
\text { deviation }\end{array}$ & $\begin{array}{c}\text { Standard error of the } \\
\text { arithmetic deviation }\end{array}$ \\
\hline Secondary school qualifications & 14 & 75.21 & 8.59 & 2.30 \\
\hline Associate degree & 37 & 75.62 & 7.92 & 1.30 \\
\hline University qualifications & 9 & 79.45 & 6.85 & 1.06 \\
\hline Total & 60 & 27.61 & 7.88 & 0.77 \\
\hline
\end{tabular}


Table 8. The significance of differences in the degree of neuroticism of respondents with different levels of educational attainment

\begin{tabular}{|c|c|c|c|c|c|}
\hline $\begin{array}{c}\text { The degree of } \\
\text { neuroticism }\end{array}$ & The square sum & $\begin{array}{c}\text { Df - degree } \\
\text { of freedom }\end{array}$ & $\begin{array}{c}\text { Arithmetic mean } \\
\text { of square }\end{array}$ & F & $\begin{array}{c}\text { Statistical } \\
\text { significance }\end{array}$ \\
\hline Among grups & 442.609 & 3 & 147.536 & 2.476 & 0.066 \\
\hline $\begin{array}{c}\text { Within the } \\
\text { groups }\end{array}$ & 6018.381 & 101 & 59.588 & & \\
\hline Total & 6460.990 & 104 & & & \\
\hline
\end{tabular}

roticism among different categories of level of educational attainment.

Based on the presented statistical analysis we can conclude that among the various categories of respondents (by level of education) there is no statistically significant difference in the degree of neuroticism $p>$ $0.05(\mathrm{p}=0.066)$.

\section{DISCUSSION}

The researches on this topic are scarce and there is not enough information so that this work can serve as an engine works on this or a similar topic. The results of this research show that people with experience of domestic violence have a higher degree of neuroticism than those who did not suffer violence. Avdibegović i Sinanović have undertaken researches on similar topic. The study was carried out in the Tuzla Canton region in the period from 2000 to 2002, and included 293 women aged $43 \pm 9.6$ years. Out of 283 women, 215 were psysically, psychologically, and sexually abused by their husbands. Among the abused, 107 (50.7\%) experienced a combination of various forms of domestic violence. The frequency of domestic violence was high among psychiatric patients (78.3\%). Victims of domestic violence had a significantly higher rate of general neuroticism, depression, somatization, sensitivity, obsessi- ve-compulsive symptoms, anxiety, and paranoid tendency than women who were not abused. The prevalence of posttraumatic stress disorder (PTSD) symptoms according to the type of trauma was higher in women with the history of childhood abuse (8/11) and domestic violence (53/67) than inwomen who experienced war trauma (26/57) and the loss of loved ones (24/83). The majority of 104 psychiatric patients suffered from PTSD in comorbidity with depression $(\mathrm{n}=45)$, followed by depression $(\mathrm{n}=17)$, dissociative disorder $(\mathrm{n}=$ 13), psychotic disorder $(n=7)$, and borderline personality disorder with depression $(n=7)$. The intensity of psychological symptoms, depression, and Global Severity Index for Psychological Symptoms (GSI) were in significant positive correlation with the frequency of psychological $(\mathrm{r}=0.45, \mathrm{P}<0.001)$, physical $(\mathrm{r}=0.43$, $\mathrm{P}$ $<0.001)$, and sexual abuse $(\mathrm{r}=0.37, \mathrm{P}<0.001)(11)$.

\section{CONCLUSION}

It remains an open question, and it is necessary to longitudinally examine what is the role of violence against women in the emergence neurotic and other disorders. It is discovered that there is a statistically significant difference in neuroticism among respondents who were suffering some form of violence and those who have not.

\title{
Sažetak
}

\section{KORELACIJA IZMEĐU PORODIČNOG NASILJA NAD ŽENAMA I NEUROTICIZMA}

\author{
Numanovic S. Almedina, ${ }^{1}$ Jovicic M. Milena ${ }^{2}$ \\ 1 Internacionalni univerzitet Novi Pazar, Novi Pazar, Srbija \\ 2 Klinički centar Kragujevac, Klinika za psihijatriju, Kragujevac, Srbija
}

Cilj: Cilj studije je bio da se utvrdi stepen korelacije između porodičnog nasilja nad ženama i neuroticizma. Socio-demografske karakteristike su takođe poređene.

Metod: Istraživanje je obuhvatilo 120 žena iz Novog Pazara i Sjenice, 60 žena koje su bile žrtva porodičnog na- silja i 60 žena koje nisu bile žrtve nasilja. Stepen neuroticizma testiran je opštim testom za neuroticizam.

Rezultati: Postoji statistički značajna razlika između žena koje su bile žrtva nasilja i onih koje nisu, $\mathrm{t}=$ $2,112, p=0,039$. Aritmetička sredina stepena neuroticizma kod žena koje su bile žrtve porodičnog nasilja je 
78,89, a kod onih koje nisu 38,69. Postoji statistički značajna razlika između udatih i neudatih žena koje su bile žrtve nasilja, kod udatih je veći stepen neuroticizma. Ispitanici koji su imali veći stepen neuroticizma su duži vremenski period patili od onih sa nižim stepenom neuroticizma, razlika je statistički značajna. $\mathrm{Ne}$ postoji statistički značajna razlika u stepenu neurotici-

\section{REFERENCES}

1. Korać H. Kriminologija/maloletničko prestupništvo. 1. izd. Kiseljak: Pravni fakultet; 2011.

2. Ignjatović T. Nasilje u porodici i institucionalna zaštita. 1. izd. Beograd: Autonomni ženski centar; 2010.

3. Službeni glasnik RS br. 18/2005. Beograd: JP „Službeni glasnik"; 2005.

4. Tjaden P, Thoennes N. Full Report of the Prevalence, Incidence, and Consequences of Violence Against Women. Washington DC: National Institute of Justice and the Centers for Disease Control and Prevention; 2000.

5. Rusac S. Nasilje nad starijim osobama. Zagreb: Pravni fakultet; 2006.

\section{Correspondence to /Autor za korespondenciju}

Almedina Š. Numanović

ul. Vehba Kolašinca, 14

069626232

Internacionalni Univerzitet u Novom Pazaru

Milena M. Jovičić

Ul. Dragoljub Milovanović Bene

0643848877

KC Kragujevac, Psihijatrijska klinika zma među ispitanicima u odnosu na stručnu i profesionalnu kvalifikaciju.

Zaključak: Ovo ostaje otvoreno pitanje, i potrebno je dalje ispitati kakva je uloga nasilja nad ženama u nastanku neurotičnog i drugih poremećaja.

Ključne reči: nasilje nad ženama, neuroticizam, neuroza.

6. Posebni protokol Ministarstva zdravlja Republike Srbije za zaštitu i postupanje sa ženama koje su izložene nasilju, Beograd, 2011.

7. Deklaracija o eliminaciji nasilja nad ženama. Rezolucija Generalne skupštine UN 48/104. Peking, 1993.

8. Opšti protokol o postupanju i saradnji ustanova, organa i organizacija u situacijama nasilja nad ženama u porodici i u partnerskim odnosima. Beograd:Ministarstvo rada i socijalne politike; 2012.

9. Dimić P J. Osnovi psihijatrije. 2. izd. Beograd:Zavod za udžbenike i nastavna sredstva; 2000.

10. Nenadović M. Propedevtika psihijatrije, psihijatrijske dijagnostike i terapije. Priština: Medicinski fakultet; 2004.

11. Avdibegović E,Sinanović O. Consequences of domestic violence on women's mental health in Bosnia and Herzegovina. Croat Med J. 2006; 47(5): 730-41. 